\title{
6. Power struggles and the politics of knowledge production in the Burundian transitional justice process
}

Wendy Lambourne

\section{INTRODUCTION}

Burundi's transitional justice experience has been one of political struggle for control over the production and dissemination of knowledge. This is a struggle that has splintered efforts over time and undermined the pursuit of a clear and coherent program endorsed by all the major stakeholders. This power struggle has manifested as one between local, national and international actors representing policymakers, practitioners, funding agencies, civil society advocates and research scholars involved in both the formal and informal sectors of dealing with the past and building peace for the future. The way that transitional justice has been understood and negotiated by the different actors has had a profound influence on the mechanisms and programs that have been pursued and the impact these have had.

This chapter will trace the historical stages in approaches to transitional justice in Burundi, starting with the terms of the Arusha Peace Agreement and moving through to the latest manifestation of the Truth and Reconciliation Commission (TRC) which began operations towards the end of 2018. It will examine the United Nations (UN) mandate in implementing the peace agreement in relation to transitional justice and how it has come into tension with domestic politics and local elite power. This analysis is located within the context of the UN's significant role in setting international transitional justice norms and practices. The chapter will also consider attempts by the UN to influence the transitional justice discourse and practice of local civil society, while local and international civil society actors have been operating as human rights advocates and developing their own programs to support transitional justice through reintegration and reconciliation, trauma healing and peacebuilding in local communities as well as at the political level. And finally, the chapter will discuss the Burundian government's ultimate assertion 
of control over the formal transitional justice process including the production of knowledge about how, when and by whom truth, justice and reconciliation are being defined and pursued in post-civil war Burundi.

The chapter concludes by arguing for a more explicit accounting for the influence of knowledge producers on the process and outcomes of transitional justice and, in particular, a recognition of the need to coordinate efforts with transparency and mutual engagement between actors at different levels in order to better manage expectations and support a potentially transformative transition. An examination of the politics of knowledge production thus provides a unique perspective on the design of transitional justice mechanisms and how to interpret their transformative potential.

\section{TRANSITIONAL JUSTICE NORMS AND PRACTICES}

The UN has outlined four key pillars of transitional justice comprising prosecutions, truth-telling, reparations, and institutional reform. These four pillars are derived directly from the 'principles against impunity' proposed by Louis Joinet and considered by the UN Commission on Human Rights in 1997: the right to justice, the right to know, the right to reparation and the guarantee of non-recurrence (swisspeace, 2016). The UN Secretary-General added a fifth key pillar in his Guidance Note published in 2010: national consultations (UN, 2010). However, despite the expectation that the UN is therefore going to respond to the views of affected populations through 'national consultations,' this is not how things have played out in practice in Burundi, as will be discussed in this chapter.

Both of these documents reflect a normative practice that is grounded in international law and human rights discourse which, I have argued elsewhere, ignores other perspectives that could be more conducive to addressing the overall transitional justice goals of reconciliation, conflict transformation and peacebuilding (Lambourne, 2014a). The international norms and practices of transitional justice have prioritized particular interpretations of 'justice' and 'truth' that fail to take into account the multiple justice and truth needs of those affected by the violence in local communities that have been represented in alternative models put forward by transitional justice scholars.

In practice, the UN has emphasized prosecutions as the pre-eminent key pillar designed to combat impunity, based on what international legal scholar Diane Orentlicher (2007) characterizes as the 'duty to prosecute.' As a result, when negotiating transitional justice as part of a peace process in settings such as Burundi, the UN has called for the creation of a tribunal or use of existing courts to prosecute those accused of mass human rights violations, over and above the pursuit of truth and/or reparations. Truth commissions may be seen by the UN and other international actors as an acceptable interim 
alternative to prosecutions because they can satisfy the 'right to know' in the form of truth-seeking, and can also potentially address the 'right to reparation.' However, because truth commissions cannot provide the 'right to justice' in the form of prosecutions, they are regarded as inferior and insufficient in themselves (swisspeace, 2016).

The right to justice is therefore narrowly interpreted in the context of international transitional justice to refer to punitive, retributive and, sometimes, reparative justice. Restorative justice, forgiveness and reconciliation, by contrast, are rejected as inadequate goals and outcomes of transitional justice even though they are often part of traditional, informal mechanisms or included as part of truth and reconciliation commissions. Similarly, the purpose of truth recovery as articulated in the UN's guiding principles on transitional justice appears to be limited to a factual/forensic truth while failing to recognize the potential value in pursuing the more personal/narrative, social/dialogical and healing/restorative truths identified as also important by the South African Truth and Reconciliation Commission (Boraine, 2006).

Transitional justice scholars have proposed alternative models of transitional justice illustrating the lack of consensus over what constitute the key pillars and how they should be defined. In particular, some scholars place more emphasis on accountability rather than the narrower focus on prosecutions. Stephan Parmentier (2003), for example, proposed Truth, Accountability, Reparations and Reconciliation (TARR) as the four key components of his model of transitional justice. Based on his experience with the South African TRC, Alex Boraine proposed a model of transitional justice that also includes accountability rather than prosecutions, and reconciliation rather than national consultations as the fifth pillar (Boraine, 2006: 26-31). Boraine also emphasizes the importance of including the four types of truth defined by the South African TRC (ibid.: 28-9). My model proposes the concept of transformative justice and includes: accountability, comprising both restorative and retributive justice, rather than just prosecutions; knowledge and acknowledgment as a category including the four types of truth, as a form of psychosocial justice; socioeconomic justice for the future rather than just reparations for the past; political justice and structural transformation (instead of institutional reform); relationship transformation which incorporates reconciliation; as well as procedural, symbolic and ritual aspects; and principles of local ownership and capacity building (Lambourne, 2014b). My model was developed as a result of field research interviews conducted in four countries recovering after mass violence - an inductive approach combined with an application of peacebuilding and conflict transformation theories. ${ }^{1}$ By contrast, the assumption that prosecutions and rebuilding the rule of law are essential components of transitional justice reflects a human rights approach, which can sometimes be antithetical to peacebuilding. I therefore argue that the assumptions of the 
UN's legalistic human rights approach deserve interrogation and potential adaptation rather than automatic application without regard for local context (Sriram, 2009).

While alternative models and local traditional or informal approaches are promoted by transitional justice scholars and some practitioners, the UN appears not to take such alternatives seriously, especially when it seems that this would be supporting impunity for political leaders. The 'justice cascade' and the 'duty to prosecute' prevail as a global norm (Orentlicher, 2007; Sikkink, 2011). There is little recognition that other, more creative options might prove to be more appropriate in different cultural and conflict settings. This is not to suggest that local affected populations might not prioritize prosecutions, but rather that their multiple transitional justice needs are not being addressed by assuming that they do. The politics of a knowledge production lens applied to this analysis illuminates the implications for whose needs and priorities are being addressed in the pursuit of transitional justice.

The international normative focus on prosecutions has often come into conflict with the political priorities of government leaders and local elites, and may fail to take into account local civil society perspectives and needs in relation to transitional justice as part of a peacebuilding process. Local affected communities may not be offered the opportunity by the UN - or national governments - to develop alternative mechanisms tailored to meet their particular goals and priorities, especially since the permanent International Criminal Court (ICC) has come into being. Compared with earlier international and hybrid criminal tribunals, the ICC's policy on outreach incorporates the most progressive and comprehensive approach to local ownership and participation (ICC, 2006), yet in practice this promise has not been fulfilled (Goetz, 2008). Local affected populations are not directly represented in the decisions of a national government, the ICC Prosecutor or the UN Security Council to refer a case or initiate investigations, nor have they been able to influence the design or conduct of the transitional justice process controlled by the ICC. Similarly, despite the development of innovative processes of victim participation through the institution of civil parties to the Extraordinary Chambers in the Courts of Cambodia, victims have reported their dissatisfaction with their preferences not being taken into account in the design of the reparations program (Williams et al., 2018).

In this chapter I use the Burundian experience as an example to illustrate how the UN's approach to transitional justice has limited the opportunity for local civil society to develop and apply its own culturally relevant approach to transitional justice (Sriram, 2009: 123). Civil society work on trauma healing, reconciliation and peacebuilding at the micro-level in local communities was not recognized by the UN as contributing to transitional justice and peacebuilding at the macro-level. The national government, meanwhile, has rejected 
prosecutions, thereby alienating the $\mathrm{UN}$, and its subsequent pursuit of a truth and reconciliation commission at a time of political crisis has limited UN or other international involvement and has marginalized, if not silenced, human rights civil society advocates who are under threat or in exile.

I consider the impact of these competing transitional justice norms and discourses on the production of knowledge about transitional justice in Burundi and its various material manifestations. Before analyzing further the significance and impact of this battle for control over discourse and practice, this chapter will first review the violence and civil war context of the Burundian transitional justice process. It will then examine the dynamics of negotiations about transitional justice priorities and mechanisms, including the conduct and outcome of national consultations; the work of the transitional justice reflection group (Groupe de Réflexion sur la Justice Transitionnelle or GRJT); the UN's civil society support mechanism, FONAREC (Forum National des Relais Communautaire en Justice de Transition, or Forum of Community Facilitators in Transitional Justice); the Quaker Burundi model of transitional justice developed in response to a scholar/practitioner workshop; and the TRC established and implemented by the national government with support from selected civil society actors.

The data for this analysis have been drawn from field research and interviews conducted during multiple visits to Burundi between 2012 and 2018 with members of local civil society in the capital, Bujumbura, the regional town of Gitega and in two other rural provinces, and my observations during a workshop on transitional justice that I ran for the Quaker Peace Network in Burundi in July 2013 and the presentation of the Quaker transitional justice model to a public forum in June $2014 .^{2}$ I have also met with and interviewed staff of the UN mission's Transitional Justice Unit (TJU), international donors, the Burundian government and international non-governmental organizations, and Burundians in exile in Rwanda since the political crisis of April 2015.

\section{CYCLES OF VIOLENCE AND CIVIL WAR IN BURUNDI}

Engaging in telling the story of conflict in Burundi is itself an act of knowledge production, depending on when the story starts and whose narratives are privileged in the telling. There is general agreement that Burundi has experienced cycles of political and inter-ethnic violence for more than 40 years, starting soon after gaining independence from Belgium in 1962, and including a civil war during which approximately 300,000 people died and many more were wounded, internally displaced or became refugees. The last of the rebel groups joined the ceasefire in 2008 following the signing of the Arusha Peace and Reconciliation Agreement which had signaled the official ending of the war eight years earlier (Vandeginste, 2012). ${ }^{3}$ Violent coups had become a political 
strategy, with factional splits in the Hutu rebel movement and divisions among the Tutsi elite fueling the conflict (Lemarchand, 1996).

Beyond and beneath these broad, surface-level observations lies a contested history filled with memories of pain and struggle that continue to haunt the political landscape and influence the construction of reality for ordinary Burundians. Accusations of genocide have been made in both directions, focusing on the crisis of 1972 when 200,000 Hutu were massacred by the Tutsi army in response to a violent uprising against Tutsi rule, and the revenge killing of 50,000 Tutsi following the murder of the Hutu president in 1993 which marked the onset of the civil war (Watt, 2016). In the absence of any acknowledgment from either group for the mass atrocities and continuing violence, both Hutu and Tutsi have observed that: 'Everyone in Burundi is a victim, no-one is a perpetrator.' 4 These competing narratives and realities experienced by the majority Hutu and minority Tutsi ethnic groups, and reflected in the internal political divisions that cut across ethnic identities, have overshadowed those of the marginalized Twa ethnic group who have remained virtually voiceless in the conflict and subsequent transitional justice and peacebuilding efforts. ${ }^{5}$

The Arusha Peace Agreement ushered in, in the election in 2005, a power-sharing government for the first time in Burundian history, with a Hutu president and Tutsi vice-president in rotating roles (Watt, 2016: 77). However, this power-sharing arrangement eventually broke down, to be taken over by political party allegiances associated to varying degrees with ethnic identities, and the eventual emergence of the dominant ruling party of Hutu President Pierre Nkurunziza. In April 2015, Nkurunziza confirmed his intention to stand for a third term in office, which triggered the onset of non-violent protests, the use of force in response and a return to inter-ethnic tensions and violence as a political strategy (Lambourne, 2018).

\section{TRANSITIONAL JUSTICE IN BURUNDI: FROM UN TO GOVERNMENT CONTROL}

The 2000 Arusha Agreement provided a framework for transitional justice in Burundi, including the establishment of a Truth and Reconciliation Commission (Commission de la Verité et Réconciliation, or CVR) in order to investigate the crimes committed in Burundi, promote reconciliation, and clarify and rewrite the country's history (Taylor, 2013a). It also stipulated that the transitional government would request the UN Security Council to set up an international judicial commission of inquiry, which would be followed by a request for an international criminal tribunal for Burundi should evidence be found that acts of genocide, crimes against humanity or war crimes had been committed (Vandeginste, 2012). An interim agreement to establish a special chamber within the Burundian court system was replaced by the proposal for 
a special tribunal, which was later shelved following the failure of negotiations between the UN and the Burundian government (International Center for Transitional Justice (ICTJ), 2011; Taylor, 2013a; Vandeginste, 2012).

The rebels' preference for a Truth and Reconciliation Commission subsequently prevailed, but not until more than 15 years later as the UN tried to exert its influence over the process - preferring the establishment of a tribunal - and the ruling party in Burundi resisted the establishment of any transitional justice measures, fearing that even a TRC could threaten the safety and power of the ruling elite (Vandeginste, 2012: 3). Legislation for the establishment of the CVR was adopted in December 2004, but implementation was delayed until after the government agreed to national consultations on transitional justice following the recommendation of the Kalomoh Report arising from the UN assessment mission that was submitted in March 2005 (Vandeginste, 2009). The national consultations in Burundi arose because of the insistence of the UN, and the terms of the process were set out in an agreement signed in November 2007 between the Burundian government, local civil society and the UN (ICTJ, 2011). Consistent with the UN's subsequently published guiding principles, these terms included an assurance that the consultations would be independent, balanced and inclusive of women and different categories of victims (ICTJ, 2011; UN, 2010). At this stage, the UN was able to exert some control over the process, but the Burundian government was beginning to exercise its power to shape the outcome.

The consultations did not give respondents the opportunity to express their preference on the type of transitional justice mechanism, but instead asked about specific aspects of each of the four key pillars predefined as constituting a truth and reconciliation commission in order to seek the truth, and a special tribunal to achieve prosecutions, along with reparations and institutional reform (Government of Burundi and UN, 2010). The consultations also asked about the period of inquiry to be covered by transitional justice, and about what Burundians thought would assist in building reconciliation and a sustainable peace. Other than these two more open questions, it is clear that the UN was able to impose not only its predefined four pillars but also the types of transitional justice mechanisms available to Burundians.

The results of the national consultations were released in a joint report by the Government of Burundi and the UN in April 2010 and were interpreted as revealing majority support for the establishment of a TRC, even though the consultations did not really provide any alternative. The international human rights NGO Impunity Watch, meanwhile, noted that the consultations also revealed a preference for a mixed national and international composition that would maximize the potential for an independent TRC with a mandate to investigate the full range of crimes from independence in 1962 until the end of the civil war in 2008, as well as provision for reparations (Boloquy 
et al., 2013). The government was able to ignore the public preference for a mixed truth commission, however, and instead, following the 2010 elections, established a technical committee to elaborate the law for the creation of the TRC and present it to parliament. On 18 October 2011, the committee, which was composed of seven members appointed by the government, released its report - known as the Kavakure Report after the head of the committee, Minister Laurent Kavakure. Kavakure was then special adviser to the president after having served previously as ambassador to Belgium and foreign affairs minister. His key role on the technical committee suggests that the report's recommendations for the planned CVR would not be independent of government power and interests. By this stage, the balance of power had clearly shifted to the Government of Burundi exercising its sovereignty as it emerged from a peace process dominated by the UN.

On the other hand, as one of my informants explained, it seems that civil society through the GRJT did have some influence in relation to the drafting of the Kavakure Report. ${ }^{6}$ The GRJT was formed in 2008 and was convened originally by a local Burundian NGO, Centre d'Alerte et Prévention de Conflits (CENAP), and later by international NGOs, including Impunity Watch and Global Rights. ${ }^{7}$ The aim of the group was to enable information exchange and to strengthen civil society involvement in the transitional justice process. Along with the UN and other local civil society groups, the GRJT commented on the Kavakure Report and its members made submissions to the government regarding subsequent versions of the draft law for the establishment of the CVR, but with minimal, if any, impact. ${ }^{8}$

The president announced that a TRC would be launched by the 50th anniversary of independence on 1 July 2012 (Vandeginste, 2012), and several draft versions of a law with guiding principles for the proposed CVR were presented to parliament by the technical committee. The UN and international and local civil society through the GRJT actively opposed the draft law on various grounds, including that it failed to comply with international standards and best practices for truth commissions, and that it did not reflect the wishes of the population as expressed in the national consultations (Impunity Watch, 2013). The third draft of the law, which was presented to parliament in December 2012, showed that civil society lobbying had made no impact, and furthermore included 'a number of revisions to the original version of the draft law that mark[ed] a clear regression in the protection of the rights of victims in Burundi' (Impunity Watch, 2013: 3). It included amendments that provided for pardon in exchange for confessions (conditional amnesty) and gave the Burundian government the sole authority to nominate and select the commissioners instead of opening the process to public participation (Boloquy et al., 2013). This development was not surprising given that the government included a number of former rebel leaders who could be accused of genocide, 
war crimes and crimes against humanity through the CVR, and who thus had a vested interest in maximizing their control of the commission (Boloquy et al., 2013). In the end there was an open nomination process, but the selection of commissioners from those nominated was made by the government in a non-transparent process. ${ }^{9}$

By contrast, 53 percent of respondents in the national consultations rejected political involvement in the appointment of the commissioners, fueled by mistrust of their political leaders, and 77 percent preferred to see a hybrid commission comprising both foreign and Burundian commissioners as a means to counter political influence and potential corruption (Boloquy et al., 2013). Approximately 88 percent of respondents indicated that civil society should be involved in selecting the commissioners, while an overwhelming majority (93 percent) of respondents believed that the commissioners should include members of civil society, compared with 73 percent who thought they should include representatives from the government (Government of Burundi and UN, 2010). Under the guise of state sovereignty, the Burundian government indicated that it would exclude international commissioners and declined to allow an international presence during the nomination process (Impunity Watch, 2013). Concern was expressed by both local and international NGOs about the implications of the lack of international involvement in the CVR for witness protection, especially in the context of government intimidation and extrajudicial killings. The draft legislation was also seen as inadequate in terms of accounting for gender sensitivity and witness protection more generally (Impunity Watch, 2013). These and other changes in the draft law signaled the government's intention to retain political control over the mandate and functioning of the CVR, going against most of the advice of the UN and the preferences of civil society and the general population. ${ }^{10}$

The law to establish the CVR was finally passed and promulgated by the president in May 2014, and operations commenced in March 2016 after the results of a much-criticized nomination process for the commissioners were announced in December 2014. Some Burundian local civil society representatives did not stand because of their objections to the process, while others nominated themselves in the hope that if they were selected they could make a positive difference to the work of the commission. ${ }^{11}$ Of the 11 selected commissioners, six were religious leaders, two were representatives of the ruling party, two were representatives of opposition political parties, ${ }^{12}$ and one was a senator and member of the minority Batwa ethnic group - all religious or political party representatives, and no representatives of civil society who might be considered neutral, professional or likely to criticize the ruling party (Impunity Watch, 2014). ${ }^{13}$ Four were women, as required by the legislation, six were Hutu and four were Tutsi. The commissioners were chosen by the 
government from a group of 33 pre-selected candidates from a total of 725 nominations.

The ruling party of the Burundian government thus continued to assert its control over the transitional justice process, delaying the creation of the CVR until a time when there was no freedom of speech or security for those who give testimony or criticize the government (Forum pour le Renforcement de la Société Civile (FORSC), 2016). The UN, meanwhile, maintained a mandate in its political missions to support transitional justice through the TJU of the UN Office in Burundi (BNUB) which replaced the UN Integrated Office in Burundi (BINUB) and ran from January 2011 until the end of 2014. ${ }^{14}$ Impotent to affect the Burundian government's policies and facing the threat of expulsion from the country, the TJU turned its attention to supporting civil society engagement in transitional justice in addition to its existing project on witness protection, preparing for the eventual creation of the CVR. ${ }^{15}$ However, despite significant investment, the TJU's efforts were not effective in targeting the needs of civil society. Civil society representatives interviewed in Burundi in 2012 and 2013 revealed their disappointment with the UN's approach: they reported a lack of support for transitional justice-related programs in local communities from the BNUB/TJU because of constraints in the type of funding available (Lambourne, 2018). They also expressed surprise about the TJU's approach to creating the FONAREC/JT independently of existing civil society groups working on transitional justice in Burundi, which led to its eventual disbandment because of a lack of sustainability (Lambourne, 2014a). As discussed further below, FONAREC/JT was a flawed creation in a number of ways, including its failure to build on the existing capacity, experience and involvement of CSOs in transitional justice, and its focus on transmitting knowledge about the key pillars of transitional justice as defined by the UN rather than on an authentic engagement in understanding local civil society perspectives and priorities (Lambourne, 2014a). In this way, the UN could be seen as trying to reassert its control over knowledge production in relation to transitional justice in Burundi. ${ }^{16}$

Despite the continuing presence of BNUB, the influence of the UN over transitional justice in Burundi was gradually reduced, from the release of the Kalomoh Report on the UN assessment mission and the passing of UN Security Council Resolution 1606 in 2005 endorsing the report's recommendations (Annan, 2005; UN Security Council Resolution 1606, 2005), with the last flurry of impact appearing to be the conduct of the national consultations in 2009 and release of the ensuing report in 2010. Local and international civil society actors in Burundi were asking why the UN did not do more to ensure that the CVR was established in a timely fashion, while the victims and perpetrators going back to 1962 were still alive, and, furthermore, why the 
government was allowed to ignore the results of the national consultations in terms of the proposed CVR mandate. ${ }^{17}$

Local civil society actors were also questioning their own lack of influence over the transitional justice process, despite evidence that in other areas civil society had been successful in influencing government policy especially when it engaged in media campaigns. ${ }^{18}$ Vandeginste (2012: 362) maintained that 'societal pressure from below has not been very significant,' at least in terms of its impact on government decision-making in relation to transitional justice, despite extensive civil society lobbying efforts through the GRJT. In addition to the national consultations, several international and local civil society initiatives reported on research revealing further insights into the needs, expectations and priorities of victims and others in the Burundian population (Boloquy et al., 2013; Taylor, 2013a). As with the national consultations, the government appeared to be ignoring the existing efforts at civil society participation in the design and implementation of transitional justice processes in Burundi. Essentially, the design and implementation of the CVR has been in the hands of the Burundian government, which has shown itself unlikely to support a robust investigation through a truth commission, far less prosecutions through the establishment of a special tribunal. The power dynamics had firmly settled with the government controlling the production of knowledge in relation to transitional justice in Burundi through the CVR, with the efforts of both the UN and international and local civil society failing to make any significant impact on the process or outcomes.

\section{THE UN AND CIVIL SOCIETY TRAINING IN TRANSITIONAL JUSTICE}

Having found itself no longer able to influence the Burundian government directly, the UN turned its attention to influencing civil society under the guise of transitional justice outreach. Through FONAREC/JT, the UN invested considerable resources in training community facilitators in its model of transitional justice with its four key pillars and emphasis on prosecutions, rather than using the opportunity to extend consultations to gather information in order to contribute to the design of transitional justice processes and a model more appropriate for the Burundian context. This mirrors the preference for training over meaningful consultations that is discussed in Chapter 7 by Njeru and Masiya. My interviews with FONAREC local facilitators in Bujumbura and Gitega revealed that training had been provided by UN 'experts' on transitional justice in a way that did not consider the opinions and input from those who participated in the program, in direct contradiction to the fifth pillar of national consultations calling for 'meaningful public participation,' 'allowing states to craft an appropriate context-specific transitional justice programme' 
and helping 'victims and other members of civil society to develop local ownership of the resulting programme' (UN, 2010).

My analysis of the FONAREC 'Guide for Community Facilitators during Transitional Justice' revealed that it was 'an information document rather than a consultation of the population' as 'that consultation had already been carried out during the national consultation' (FONAREC/JT, 2012; Lambourne, 2014a). Crucially, the FONAREC/JT guide for training community facilitators was firmly grounded in the four pillars of transitional justice from the UN Secretary-General's 2010 Guidance Note (UN, 2010). ${ }^{19}$ As such, it focused on prosecutions rather than the broader concept of accountability, and it did not include reconciliation or healing except as a subset of reparations, along with memorialization. The FONAREC guide listed under each pillar 'key messages to memorize,' reflecting an extremely prescriptive attitude towards training which confirmed the UN and international experts as the only source of knowledge about transitional justice. Transitional justice was introduced as an alien concept unrelated to existing Burundian concepts and processes, and failed to foster any meaningful sense of local ownership or participation in the transitional justice process (FONAREC/JT, 2012).$^{20}$ The guide maintained that 'since transitional justice is something new which is not known by the Burundian population, FONAREC/JT deems it necessary to organize training, information, sensitization and social mobilization activities in order to build the capacities of the Burundian population so that it can participate in that process' (ibid.: 5). The FONAREC community facilitators were empowered with information to help them 'to better understand the basic notions related to transitional justice,' but it seems they were not invited to contribute their own ideas about transitional justice (ibid.). On the other hand, the FONAREC guide did suggest that community facilitators were expected to collect views and hear concerns of victims in relation to the transitional justice process (ibid.: 10). But it seems this part of the program was never implemented. ${ }^{21}$

The FONAREC/JT process focused on training community facilitators at all levels of Burundian society throughout the country in the UN model of transitional justice, which, if successfully implemented, would have given the UN significant control over knowledge production in relation to transitional justice within the Burundian general population. While empowerment with information is important and the FONAREC process did contribute to some kind of capacity building, it was insufficient, if not counter-productive, as a means of promoting local ownership and participation in the production of knowledge for and about transitional justice in Burundi. ${ }^{22}$ 


\section{QUAKER PEACE NETWORK BURUNDI ALTERNATIVE MODEL OF TRANSITIONAL JUSTICE}

As discussed, when the UN TJU in Burundi pursued its engagement with local communities, it did so by training civil society leaders in its predefined key pillars of transitional justice, thereby imposing a restricted view of what transitional justice could entail. By contrast, the Quaker Peace Network (QPN) in Burundi challenged the UN model by proposing an alternative and culturally adapted version of the UN's five key pillars of transitional justice: accountability, truth telling, positive relations, leadership development, and community empowerment. ${ }^{23}$ The QPN Burundi Model of Transitional Justice was developed following a workshop initiated by QPN Burundi and Trauma Healing and Reconciliation Services (THARS) which I facilitated in mid-2013 which focused on a more elicitive rather than prescriptive approach to training. The workshop enabled the participants to learn about a variety of models of transitional justice proposed by international scholars and practitioners, in addition to the UN model, and to explore their own ideas about what they saw as the core concepts of transitional justice including truth, justice and reconciliation. Interestingly, the participants took what they saw as a more realistic stance by rejecting reparations as part of their model 'in recognition of the extreme poverty [in Burundi] which made it unlikely that meaningful reparations could be forthcoming' (Lambourne, 2018). In developing their model, the participants drew on their experiences working on community-based trauma healing and reconciliation in the context of transitional justice and peacebuilding in Burundi (Lambourne and Niyonzima, 2016).

The QPN Burundi group subsequently took the initiative to meet again in December 2013 to further consult with others inside and outside QPN in order to develop the model, and in June 2014 launched the model publicly in Bujumbura with a view to promoting a more effective approach to transitional justice consistent with supporting national cohesion, peace and development in their country. The public launch of the QPN Burundi model created some controversy and much lively debate among civil society actors and representatives of the government and UN because of its apparent downplaying of the call for an end to impunity emphasized by the UN and other civil society members of the GRJT. Religious leaders who were calling for forgiveness and reconciliation had already been labeled by human rights and transitional justice actors as being aligned with the government and a culture of impunity. ${ }^{24}$ As a result, the UN responded with scepticism about the motivations of any faith-based actors, including QPN Burundi, and assumed that calls for reconciliation must mean lack of accountability. Meetings of QPN civil society leaders with the UN TJU failed to make any impression on the UN's attitude to transitional justice 
priorities in Burundi, despite assurances that they were not trying to replace the UN model, but rather to propose a complementary model that could be more effective in the cultural, socioeconomic and political context of Burundi.

The efforts of the QPN Burundi network suggest an attempt to produce an alternative source of knowledge about transitional justice in Burundi, which seemed to be gaining some traction despite the controversial reception. However, since the political crisis of April 2015, the activities and influence of civil society in Burundi have been severely curtailed, and the QPN model has not been pursued except through the community programs of individual QPN member organizations. ${ }^{25}$

\section{CONCLUSION: IMPLICATIONS OF THE CONTROL OF KNOWLEDGE PRODUCTION FOR TRANSITIONAL JUSTICE}

The case study of Burundi illustrates how political leaders can exercise their sovereignty and control over the production of knowledge about transitional justice in such a way as to favour particular mechanisms and approaches as a means of controlling the production of knowledge about the past through transitional justice. The ruling party led by then President Pierre Nkurunziza has ensured that a culture of impunity and division prevails, where prosecutions have been removed as an option despite the terms of the Arusha Peace Agreement, and the CVR has been established to pursue a domestic political agenda without international involvement and active civil society participation.

The politics of knowledge production in relation to transitional justice in Burundi have thus been directly determined by who was controlling the conversation about transitional justice, its means and potential mechanisms. The design of transitional justice in Burundi was initially controlled by the UN through the implementation of the terms of the peace agreement and imposition of its model of transitional justice with its emphasis on the duty to prosecute. As argued in this chapter, the UN's influence over knowledge production about transitional justice was maintained through the conduct of national consultations, the TJU and its creation of FONAREC/JT. However, the assertion of state sovereignty and control over the design and implementation of transitional justice by the Government of Burundi through the politics of knowledge production gradually usurped the power of the UN as well as international and local civil society to control the discourse and practice of transitional justice in the country. This chapter has argued that the government manipulated the results of the national consultations to legitimize their predefined political agenda to control the national narrative about the past through the creation of the CVR instead of the pursuit of prosecutions. It has shown how the government ignored the wishes of the population as expressed 
in the national consultations in the process of designing the CVR to support this political agenda, and how civil society initiatives including the GRJT and QPN Burundi model for transitional justice have had limited impact on the transitional justice process as it has unfolded in the country.

In Burundi, the idea of promoting dialogue, participation and local ownership of transitional justice has not been fulfilled, except in the sense that the national government has been maintaining tight control over ownership of the internationally mandated, national transitional justice process. The national government ignored the recommendations arising from the national consultations, as it made changes to the legislation for establishing the CVR, so the standard mechanism promoted by the UN and agreed to by the government was looking less and less like something that was addressing the needs and priorities of the local affected communities.

It seems that respect for state sovereignty leaves the UN no choice but to regard national ownership as local ownership, which goes some way to explaining the tensions evident in the UN Guidance Note between the principles of local ownership and national consultations. This respect for state sovereignty creates a significant gap in principles of democratization and participation when the government is not open to the views of civil society and local communities. The UN guiding principle that calls for the "centrality of victims in the design and implementation of transitional justice processes and mechanisms' is reduced to empty rhetoric if the government maintains firm control over the transitional justice discourse and practice that is disconnected from the ideas and priorities of local affected communities (UN, 2010).

As argued by Kora Andrieu (2010), there is a danger in the international community's 'technocratic, one-size-fits-all approach' to transitional justice in the context of fragile, newly created post-conflict governments where excessive legalism or focus on supporting national processes can seem 'distant and remote to those who actually need it.' This was the criticism leveled against the early ad hoc international and hybrid tribunals set up by the UN, but it has continued to be a factor in the era of the ICC despite research, policies and mandates advocating a more localized approach. The fact that Burundi has until now had no tribunal, and that its truth commission has been set up during a period of political instability and without regard for the results of national consultations, is a function of the national ownership afforded by the UN, rather than the expressed wishes of the population for both accountability and a genuine process of truth-telling.

The Burundi experience highlights the tensions inherent in relationships between local communities, national governments and international organizations in the design and implementation of peacebuilding as well as transitional justice where the liberal democratic model is being imposed without consideration for local cultural alternatives. On the other hand, accountability or 
prosecutions should not be denied merely on the grounds of rejecting Western institutions of international law; as my research and that of others has revealed, retributive justice is a legitimate demand of victims and others who have experienced mass atrocity crimes (Sriram, 2009: 122-3).

In other cases in sub-Saharan Africa and further afield, political leaders have been seen to exercise their power to shape the production of knowledge in relation to transitional justice in different ways, with varying levels of influence from the international community and civil society. In Rwanda, for example, President Paul Kagame and his government have used their political power to shape the national narrative and memory of genocide in order to build a new ideology of unity and reconciliation, replacing the divisions of the past and making use of the community-based gacaca justice system to combine accountability with reconciliation and to override the potentially divisive influence of the International Criminal Tribunal for Rwanda and domestic prosecutions. In the former Yugoslavia, by contrast, national political power has been used to reinforce a continuing narrative of enmity and irreconcilable division through control of the media, education and history teaching, commemorative activities and a focus on prosecutions, where inter-ethnic tensions have remained unaddressed, if not reinforced, by the political division into separate states and the role of the international community in the Dayton Peace Accord and creation of the International Criminal Tribunal for the former Yugoslavia. In Cambodia, meanwhile, the Hun Sen government ensured that a culture of impunity was able to prevail for more than 30 years following the internationally brokered Paris Peace Agreement, and has continued to exercise its control over the functioning of the hybrid domestic-international tribunal finally established to prosecute the crimes of the surviving former Khmer Rouge leaders. The collective and moral reparations ordered by the Extraordinary Chambers in the Courts of Cambodia, as implemented by local and international civil society partners, have gone some way towards the construction of competing narratives of the past as have the community-level psychosocial interventions in Burundi.

In Burundi, there is not only privileging of the national government through the ruling party, followed by the UN and other external actors, including both governmental and non-governmental levels, there is also a bias towards who within local civil society is empowered to control the transitional justice discourse and practice in the country. In the current political climate that has prevailed since the establishment of the CVR, it is supporters of the ruling party and Hutus more generally who remain with a more influential voice in civil society while opposition supporters and many Tutsi human rights activists have been silenced along with the most marginalized, the Twa. As discussed, the mechanisms for civil society participation in the CVR, and the election of the original commissioners, have shown a clear priority for supporters of the 
ruling party, in many cases meaning that they are Hutu and not Tutsi. The subsequent appointment of new commissioners in 2018 showed more openness to including civil society representatives and a potential shift in approach, but the mandate remained under tight government control with its almost exclusive focus on uncovering the truth and mass graves from the 1972 ' genocide against the Hutu' while ignoring calls for a more 'inclusive and impartial approach' looking at other significant periods and massacres where the Tutsi have been the primary victims (OHCHR, 2020). As a result, both the processes and outcomes of the CVR, and the knowledge it will produce and reproduce about mass human rights violations in the country historically and currently, are being controlled by a particular political elite and ethnic majority. The focus on the CVR, and the form that its work has taken, are a direct result of the power of the political leaders of the ruling party who have thus been able to control the production of knowledge in the face of protest and alternative goals and methods being sought by the UN, international civil society and transitional justice actors, and significant sections of local civil society in Burundi.

As a result, the transformative potential of transitional justice in Burundi, such as could be achieved through implementation of the QPN model, for example, is not being realized. The transformation of relationships between leaders and civil society, between the different ethnic groups and between those supporting different political parties has been pursued by civil society actors such as THARS through community psychosocial programs including the Alternatives to Violence Project (AVP) (Lambourne and Niyonzima, 2016). This chapter has shown how national and international actors have ignored the transformative potential of these alternative discourses and methods and have instead sought to impose, with varying degrees of success, their own political agendas and constructions of transitional justice. Examining these developments through the lens of knowledge production politics can thus help to illuminate the conflicting dynamics of transitional justice limiting its contribution to societal transformation and peacebuilding after mass violence.

\section{NOTES}

1. Field research interviews were conducted in Rwanda (1998 and 2005), Cambodia (1999 and 2009), Timor Leste (2004) and Sierra Leone (2006).

2. I visited Burundi in May, June and December 2012, July 2013, June and December 2014, April 2015, August 2016, November 2017 and December 2018. Local and international NGOs consulted for this research included THARS, MiPAREC, CENAP, FORSC, AFSC, AMEPCI, La Benevolencija Grands Lacs, RCN Justice et Democratie, Search for Common Ground, Global Rights and Impunity Watch, as well as members of QPN Burundi and FONAREC community facilitators in Bujumbura and Gitega. The workshop I conducted was held at the THARS 
Training Center in Gitega from 9-11 July 2013 and the model was presented at a public launch in Bujumbura in June 2014.

3. The fighting continued until December 2008 when the last of the rebel groups, Palipehutu-FNL, finally agreed to disarm, but only after reassurances that they would not be arrested and prosecuted.

4. Interviews conducted by the author in Burundi between 2013 and 2015.

5. The work of THARS discussed later in this chapter includes a deliberate effort to include the Twa in community-level psychosocial programs designed to support healing and reconciliation as part of transitional justice and peacebuilding.

6. Interview conducted in Bujumbura, August 2016.

7. See Lambourne (2018) for a detailed review of the GRJT and the role of civil society in attempting to influence the transitional justice process in Burundi.

8. See Boloquy et al. (2013) and Taylor (2013a) for an analysis of the draft law and the potential for the proposed TRC to meet the needs of the local population.

9. Interviews conducted in Bujumbura, June and December 2014.

10. For an analysis of how the Burundian government was appearing to comply with international obligations in relation to transitional justice while failing to genuinely commit to their implementation, see Taylor (2013b).

11. Interviews conducted in Bujumbura, June 2014.

12. Allegedly 'nyakuri' and not genuine opposition parties. Interviews conducted in Bujumbura and Sydney, July-August 2016.

13. Meetings with local civil society members in Bujumbura, August 2016, and in Sydney since the establishment of the CVR in early 2016, considering the political nature of the appointment of commissioners and confirming the perception that none of those appointed genuinely represented civil society. This perception represented the perspective that religious leaders had been co-opted to a partisan political agenda.

14. UN Security Council resolution 2137 of 13 February 2014, which extended the mandate of BNUB to the end of 2014, included the following in relation to transitional justice: ' 15 . Calls upon the Government of Burundi to work with international partners and BNUB for the establishment of transitional justice mechanisms, including a credible and consensual Truth and Reconciliation Commission to help foster an effective reconciliation of all Burundians and durable peace in Burundi, in accordance with the results of the work of the Technical Committee, the 2009 national consultations, Security Council resolution 1606 (2005) as well as the Arusha agreement of 28 August 2000.'

15. Note that in October 2016 the UN High Commissioner for Human Rights, whose mandate included transitional justice, was expelled by the Burundian government.

16. For a discussion of such dynamics in the context of Zimbabwe, see Chapter 7 by Njeru and Masiya in this book.

17. Interviews with local and international NGO representatives conducted in Bujumbura, December 2012 and July 2013. For an analysis of the role of the UN, see also Taylor (2013b).

18. Interview with representative of local civil society media organization, Bujumbura, July 2013.

19. This training in a fixed model of four pillars contradicts the UN's third guiding principle which 'eschews one-size-fits all formulas and the imposition of foreign models' and calls for the 'identification, support for and empowerment of domestic reform constituencies to develop and implement their own transitional justice and rule of law agenda.' 
20. Interviews with FONAREC community facilitators and TJU Coordinator.

21. Interview with TJU Coordinator.

22. Interview with TJU Coordinator.

23. QPN Burundi comprises local Quaker-based civil society organizations working on trauma healing, reconciliation, peacebuilding and community development in Burundi. See Lambourne (2018) for more details on the QPN model.

24. By contrast, QPN Burundi and Quaker NGO leaders were generally perceived as politically neutral and have worked either independently or cooperatively under the banner of the GRJT.

25. Interviews conducted in Burundi in 2016 and 2018.

\section{REFERENCES}

Andrieu, K. (2010), 'Civilizing Peacebuilding: Transitional Justice, Civil Society and the Liberal Paradigm', Security Dialogue, 41 (5), 537-58.

Annan, K. (2005), 'Letter Dated 11 March 2005 from the Secretary-General Addressed to the President of the Security Council', S/2005/158, 11 March 2005, accessed 27 March 2020 at https://www.securitycouncilreport.org/un-documents/document/ Burundi-S2005158.php

Boloquy, M., S. Mawad and D. Taylor (2013), 'Victims' Perspectives on the Independence of the TRC', Impunity Watch Newsletter, Issue 2, February 2013.

Boraine, A. (2006), 'Defining Transitional Justice: Tolerance in the Search for Justice and Peace', in A. Boraine and S. Valentine (eds), Transitional Justice and Human Security: Proceedings from a Conference Held in Somerset West, South Africa from March 28 to April 1, 2005, New York: International Center for Transitional Justice, pp. 22-37.

Forum National des Relais Communautaires pour la Justice de Transition (2012), 'Le Guide du Relais Communautaire en Justice de Transition', UNHCHR, September 2012.

Forum pour le Renforcement de la Société Civile (2016), 'Au-delà d'une Mission, la CVR a une Responsabilité Historique et Doit s'Abstenir d'Initier la Recherche de la Vérité à Sens Unique', Report, November 2016.

Goetz, M. (2008), 'The International Criminal Court and its Relevance to Affected Communities', in N. Ward and P. Clark (eds), Courting Conflict? Justice, Peace and the ICC in Africa, London: Royal African Society.

Government of Burundi and UN (2010), 'Rapport des Consultations Nationales sur la Mise en Place des Mechanismes de Justice de Transition au Burundi', 20 April 2010, accessed 27 March 2020 at https://www.ohchr.org/Documents/Countries/BI/ RapportConsultationsBurundi.pdf

Impunity Watch (2013), 'Burundi's Draft Law on the Proposed Truth and Reconciliation Committee', Policy Brief, 28 January 2013, accessed 27 March 2020 at https://www.impunitywatch.org/post/burundi-s-draft-law-on-the-proposed -truth-and-reconciliation-committee

Impunity Watch (2014), 'Sincerity of Burundi's Commitment to Transitional Justice under Scrutiny as TRC Commissioners Sworn in: Four-Year TRC Mandate Officially Begins', Policy Brief, December 2014.

International Center for Transitional Justice (2011), 'The Transitional Justice Process in Burundi' (in French), ICTJ Briefing, 18 April 2011, accessed 27 March 2020 
at https://www.ictj.org/sites/default/files/ICTJ-Burundi-Processus-de-Justice-2011 -French.pdf

International Criminal Court (2006), 'Strategic Plan for Outreach of the International Criminal Court', ICC-ASP/5/12, 29 September 2006, accessed 27 March 2020 at https://www.icc-cpi.int/NR/rdonlyres/FB4C75CF-FD15-4B06-B1E3 -E22618FB404C/185051/ICCASP512_English1.pdf

Lambourne, W. (2014a), 'What are the Pillars of Transitional Justice? The United Nations and the Justice Cascade in Burundi', Macquarie Law Journal, 13, 41-60.

Lambourne, W. (2014b), 'Transformative Justice, Reconciliation and Peacebuilding', in S. Buckley Zistel, T. Koloma Beck, C. Braun and F. Mieth (eds), Transitional Justice Theories, New York: Routledge, pp. 19-39.

Lambourne, W. (2018), 'Cooperation and Conflict: Civil Society Resistance and Engagement with Transitional Justice in Burundi', in J. Brankovic and H. van der Merwe (eds), Advocating Transitional Justice in Africa: The Role of Civil Society, Cham: Springer, pp. 111-33.

Lambourne, W. and D. Niyonzima (2016), 'Breaking Cycles of Trauma and Violence: Psychosocial Approaches to Healing and Reconciliation in Burundi', in P. Gobodo-Madikizela (ed.), Breaking Intergenerational Cycles of Repetition: A Global Dialogue on Historical Trauma and Memory, Opladen: Barbara Budric Publishers, pp. 291-307.

Lemarchand, R. (1996), Burundi: Ethnic Conflict and Genocide, Cambridge: Woodrow Wilson Center Press and Cambridge University Press.

Office of the High Commissioner for Human Rights (2020), Oral Briefing of the Commission of Inquiry on Burundi at 43rd Human Rights Council Session, Geneva, 9 March 2020.

Orentlicher, D. F. (2007), “"Settling Accounts” Revisited: Reconciling Global Norms with Local Agency', International Journal of Transitional Justice, 1 (1), 10-22.

Parmentier, S. (2003), 'Global Justice in the Aftermath of Mass Violence. The Role of the International Criminal Court in Dealing with Political Crimes', International Annals of Criminology, 41 (1), 203-23.

Sikkink, K. (2011), The Justice Cascade: How Human Rights Prosecutions are Changing World Politics, New York: W. W. Norton.

Sriram, C. L. (2009), 'Transitional Justice and the Liberal Peace', in E. Newman, R. Paris and O. Richmond (eds), New Perspectives on Liberal Peacebuilding, Tokyo: United Nations University Press, pp. 121-3.

swisspeace (2016), 'A Conceptual Framework of Dealing with the Past: Holism in Principle and Practice', Essential, accessed 27 March 2020 at https://www .swisspeace.ch/assets/publications/downloads/Essentials/7bdf926517/A-Conceptual -Framework-for-Dealing-with-the-Past-Essential-16-swisspeace.pdf

Taylor, D. (2013a), 'Truth under the Avocado Trees: Local Needs and Burundi's TRC: Whither the Truth?', Journal of Eastern African Studies, 7 (3), 450-70.

Taylor, D. (2013b), 'We Have no Influence: International Discourse and the Instrumentalisation of Transitional Justice in Burundi', Stability: International Journal of Security and Development, 2 (3), 1-10.

United Nations (2010), 'Guidance Note of the Secretary-General: United Nations Approach to Transitional Justice, DPA/UNSG/2010-00904, 10 March 2010, accessed 27 March 2020 at https://www.un.org/ruleoflaw/files/TJ_Guidance_Note _March_2010FINAL.pdf 
United Nations Security Council Resolution 1606 (2005), 'The Situation in Burundi', S/RES/1606, 20 June 2005, accessed 27 March 2020 at http://unscr.com/en/ resolutions/ 1606

Vandeginste, S. (2009), 'Transitional Justice in Burundi: A Long and Winding Road', in K. Ambos, J. Large and M. Wierda (eds), Building a Future on Peace and Justice, Berlin: Springer, pp. 393-422.

Vandeginste, S. (2012), 'Burundi's Truth and Reconciliation Commission: How to Shed Light on the Past While Standing in the Dark Shadow of Politics', International Journal of Transitional Justice, 6 (2), 355-65.

Watt, N. (2016), Burundi: The Biography of a Small African Country, London: Hurst \& Company.

Williams, T., J. Bernath, B. Tann and S. Kum (2018), Justice and Reconciliation for the Victims of the Khmer Rouge? Victim Participation in Cambodia's Transitional Justice Process, Marburg: Centre for Conflict Studies; Phnom Penh: Centre for the Study of Humanitarian Law; Bern: swisspeace. 